\title{
REVIEW
}

\section{The Eye of the Storm: COVID-19 Vaccination and the Eye}

\author{
Xin Le Ng • Bjorn Kaijun Betzler · Sean Ng - Soon Phaik Chee · \\ Lakshminarayanan Rajamani · Amit Singhal · Andres Rousselot · \\ Carlos E. Pavesio · Vishali Gupta · Marc D. de Smet · Rupesh Agrawal (1)
}

Received: September 28, 2021 / Accepted: October 21, 2021 / Published online: December 16, 2021

(c) The Author(s) 2021

\section{ABSTRACT}

The COVID-19 pandemic has galvanized the global response towards the development of new vaccines based on novel technologies at an unprecedented pace. Since the widespread

\section{L. Ng · R. Agrawal ( $₫)$}

National Healthcare Group Eye Institute, Tan Tock Seng Hospital, Singapore 308433, Singapore e-mail: rupesh_agrawal@ttsh.com.sg

B. K. Betzler · R. Agrawal

Yong Loo Lin School of Medicine, National

University of Singapore, Singapore, Singapore

S. Ng $\cdot$ R. Agrawal

Lee Kong Chian School of Medicine, Singapore, Singapore

\section{S. P. Chee}

Singapore National Eye Centre, Singapore, Singapore

\section{S. P. Chee · L. Rajamani · R. Agrawal}

Singapore Eye Research Institute, The Academia, Singapore, Singapore

\section{S. P. Chee}

Department of Ophthalmology, Yong Loo Lin School of Medicine, National University of Singapore, Singapore, Singapore

\section{S. P. Chee · L. Rajamani · R. Agrawal}

Department of Ophthalmology and Visual Sciences Academic Clinical Program, Duke-NUS Medical School, Singapore, Singapore implementation of vaccination campaigns, case reports on vaccines' systemic side effects, including ocular manifestations, have emerged. Since administered vaccines are generally not able to cause the disease in the recipient, or induce an immune response against the pathogen, we hypothesize that the development of

\section{A. Singhal \\ A*STAR ID Labs \& Singapore Immunology Network $(\mathrm{SIgN})$, Singapore, Singapore}

\section{A. Rousselot \\ Department of Ophthalmology, Universidad del Salvador, Buenos Aires, Argentina \\ C. E. Pavesio - R. Agrawal \\ Moorfields Eye Hospital, NHS Foundation Trust, London, UK \\ V. Gupta \\ Department of Ophthalmology, Advance Eye Centre, Post Graduate Institute of Medical Education and Research, Chandigarh, India}

M. D. de Smet

MicroInvasive Ocular Surgery Clinic, Lausanne, Switzerland

M. D. de Smet

Department of Ophthalmology, University of Leiden, Leiden, The Netherlands 
ocular phenomena post-COVID-19 vaccination may occur via an immune response elicited by the vaccine. Of many, the most common ocular adverse events include facial nerve palsy, central venous sinus thrombosis and acute anterior uveitis. These COVID-19 vaccine-induced ocular (CVIO) adverse events could resemble the ocular findings in some of the COVID-19 patients. This review will provide a comprehensive overview of published ocular side effects potentially associated with COVID-19 vaccination and serve as a springboard for further research into CVIO adverse events.

Keywords: Adverse events; COVID-19; Ocular manifestation; Side effects; Uveitis; Vaccination; Vaccine

\section{Key Summary Points}

A comprehensive overview of published ocular side effects potentially associated with COVID-19 vaccination

Ocular phenomena post-COVID-19 vaccination may occur via an immune response elicited by the vaccine

COVID-19 vaccine-induced ocular (CVIO) adverse events could resemble the ocular findings in some COVID-19 patients

The ocular adverse events related to COVID-19 vaccines have a remarkably low incidence especially when considering the extremely large numbers of people that have been inoculated worldwide

It is often easily treated, and the worst cases are still not as bad as having the COVID-19 infection

This review could be beneficial to practicing ophthalmologists and clinicians in identifying patients who may be at a higher risk of ocular inflammation so that protocols for close monitoring and education of the patients at risk can be designed and implemented

\section{INTRODUCTION}

Coronaviruses are ubiquitous and can affect several organs including the eye. Currently, there are a total of seven different strains of coronaviruses that infect humans. Common cold coronavirus strains include 229E (alphacoronavirus), NL63 (alphacoronavirus), OC43 (betacoronavirus) and HKU1 (betacoronavirus). On the other hand, pathogenic strains include MERS-CoV (betacoronavirus), SARS-CoV (betacoronavirus) and, most recently, SARS-CoV-2 [1]. Murine models have revealed a progressive retinal degeneration associated with autoimmune reactivity early after virus infection [2]. The disease was shown to be biphasic. During the initial infection, the virus and associated viral particles were found in both the retina and pigment epithelium that lasted a week, with retinal persistence and prolonged expression of ribonucleic acid (RNA) detected via in situ hybridization [3].

A chronic degenerative phase develops in susceptible strains such as BALB/c mice, leading to a progressive loss of photoreceptors, retinal pigment epithelium (RPE) and ganglion cells mediated, in part, by a reactivity to autoantigens [4]. It should therefore come as no surprise that coronaviruses can lead to both an acute ocular presentation and a more delayed immune-mediated response in susceptible humans.

In addition, in both experimental models and natural disease, SARS-CoV-2 has been associated with uveitis and ocular immune responses [5, 6]. Known ocular manifestations of COVID-19 infection include conjunctivitis, episcleritis, uveitis, vascular changes in the retina such as retinal hemorrhages, cotton wool spots, dilated veins and tortuous vessels, and optic neuritis, ocular motility deficits from cranial nerve palsies, ocular myasthenia gravis, acute dacryoadenitis and epiphora [7-19].

This review of the available literature provides an overview of ocular side effects possibly associated with COVID-19 vaccines. A review of the incidence of such conditions would be beneficial to practicing ophthalmologists and clinicians in identifying patients who may be at 
a higher risk of ocular adverse events so that protocols for close monitoring and education of the patients at risk can be designed and implemented [20].

This review adhered to the tenets of the Declaration of Helsinki, and as the research does not contain any patient data, specific ethical clearance was not required for this study based on our ethics committee guidelines. This article is based on previously conducted studies and does not contain any new studies with human participants or animals performed by any of the authors.

\section{COVID-19 VACCINE-ASSOCIATED OCULAR INFLAMMATION}

Vaccines have been reported to induce ocular side effects, including conjunctival and eyelid reactions, optic neuritis and intraocular inflammation [21-25]. Furthermore, live attenuated vaccines may cause ocular infection from the organisms derived, especially in at-risk groups, including the immunosuppressed $[26,27]$. The adjuvants included in COVID-19 mRNA vaccines stimulate innate immunity through endosolic or cytoplasmic nucleic acid receptors including Toll-like receptors (TLRs) [28]. Several autoimmune diseases, particularly connective tissues diseases, are associated with an altered nucleic acid metabolism and processing, which may trigger an immune response following immunization [29, 30]. Given the scale of the current vaccination campaign against COVID-19, acute and chronic inflammatory responses have been observed [31]. These include myocarditis [32], kidney transplant rejection [33] and vaccine-induced thrombotic thrombocytopenia (VITT) [34]. While cases of uveitis triggered or re-activated by SARS-CoV-2 have been described, there is a lack of literature describing possible failure of immune privilege or maladaptive immunity in response to COVID-19 vaccination in some susceptible individuals [35].

To date, there are numerous published and unpublished reports of ocular inflammation potentially associated with COVID-19 vaccination (Table 1). The COVID-19 vaccines include the mRNA vaccine (BNT162b2, Pfizer-BioNTech; mRNA-1273, Moderna), protein subunit vaccine (NVX-CoV2373, Novavax), vector vaccine (Ad26COVS1, Janssen Johnson \& Johnson; AZD1222, Oxford-AstraZeneca) and whole virus (PiCoVacc, Sinovac; BBIBP-CorV, Sinopharm). In order of frequency of cases reported, where ' $n$ ' is the combined total number of subjects in the relevant studies for each category, the ocular complications reported were Bell's/facial nerve palsy $(n=30)$, central venous sinus thrombosis and thrombosis $(n=15)$, acute anterior uveitis $(n=9)$, acute macular neuroretinopathy $(n=8)$, corneal graft rejection $(n=6)$, anterior scleritis $(n=5)$, panuveitis $(n=4)$, posterior uveitis $(n=3)$, cranial nerve palsy (excluding Bell's/facial nerve palsy) $(n=1)$, central serous chorioretinopathy $(n=1)$, Vogt-Koyanagi-Harada disease $(n=2)$, central retinal vein occlusion $(n=1)$, bilateral multifocal choroiditis $(n=1)$, episcleritis $(n=1)$, intermediate uveitis $(n=1)$, paracentral acute middle maculopathy $(n=1)$, subretinal fluid $(n=1)$ and bilateral optic neuritis $(n=1)$, in a total of 89 subjects (Fig. 1). The reported entities appear to overlap with the ocular manifestation reported in patients infected with COVID-19, suggesting a common pathway (possibly TLR) between virus and vaccine-mediated immune response in humans. In addition, there are several unpublished reports of patients with uveitis post-COVID-19 vaccination. We will briefly describe some of the adverse effects reported following COVID-19 vaccination below. 
Table 1 Overview of studies reported in the literature related to ocular side effects secondary to COVID-19 vaccination

\begin{tabular}{|c|c|c|c|c|}
\hline Study & Summary & $\begin{array}{l}\text { Vaccine } \\
\text { studied }\end{array}$ & $\begin{array}{l}\text { Time to onset of } \\
\text { symptoms }\end{array}$ & $\begin{array}{l}\text { Ocular symptoms } \\
\text { and number of cases } \\
(n)\end{array}$ \\
\hline $\begin{array}{l}\text { Ozonoff et al. [36] } \\
\text { Bell's palsy and SARS-CoV-2 } \\
\text { vaccine }\end{array}$ & $\begin{array}{l}\text { A case series of numerical } \\
\text { imbalance in incidences of } \\
\text { Bell's palsy between } \\
\text { vaccine and placebo arms } \\
\text { during trials }\end{array}$ & $\begin{array}{l}\text { BNT162b2, } \\
\text { mRNA- } \\
1273\end{array}$ & NA & $\begin{array}{l}\text { NA } \\
n=7\end{array}$ \\
\hline $\begin{array}{l}\text { Shemer et al. [37] } \\
\text { Association of COVID-19 } \\
\text { vaccination and facial nerve } \\
\text { palsy: a case-control study }\end{array}$ & $\begin{array}{l}\text { A case-control study of } \\
\text { association between facial } \\
\text { nerve palsy between } \\
\text { vaccinated and } \\
\text { unvaccinated groups }\end{array}$ & BNT162b2 & $9-14$ days & $\begin{array}{l}\text { NA } \\
n=21\end{array}$ \\
\hline $\begin{array}{l}\text { See et al. }[74] \\
\text { US Case reports of cerebral } \\
\text { venous sinus thrombosis } \\
\text { with thrombocytopenia } \\
\text { after Ad26COV1 } \\
\text { vaccination, } 2 \text { March to } 21 \\
\text { April } 2021\end{array}$ & $\begin{array}{l}\text { A case series of incidences of } \\
\text { cerebral venous sinus } \\
\text { thrombosis with } \\
\text { thrombocytopenia } \\
\text { reported post-vaccination } \\
\text { via passive reporting } \\
\text { system }\end{array}$ & Ad26COVS1 & 6-17 days & $\begin{array}{l}\text { Fixed, dilated pupil, } \\
\text { gaze deviation, } \\
\text { undefined visual } \\
\text { changes } \\
n=3\end{array}$ \\
\hline $\begin{array}{l}\text { Castelli et al. }[75] \\
\text { Cerebral venous sinus } \\
\text { thrombosis associated with } \\
\text { thrombocytopenia post- } \\
\text { vaccination for COVID-19 }\end{array}$ & $\begin{array}{l}\text { A case report of post- } \\
\text { vaccination cerebral } \\
\text { venous sinus thrombosis }\end{array}$ & AZD1222 & 11 days & $\begin{array}{l}\text { Slight visual } \\
\text { impairment } \\
n=1\end{array}$ \\
\hline $\begin{array}{l}\text { Bayas et al. [39] } \\
\text { Bilateral superior ophthalmic } \\
\text { vein thrombosis, ischemic } \\
\text { stroke and immune } \\
\text { thrombocytopenia after } \\
\text { ChAdOx1 nCoV-19 } \\
\text { vaccination }\end{array}$ & $\begin{array}{l}\text { A case report of bilateral } \\
\text { superior ophthalmic vein } \\
\text { thrombosis post- } \\
\text { vaccination }\end{array}$ & AZD1222 & 10 days & $\begin{array}{l}\text { Conjunctival } \\
\text { congestion, } \\
\text { retroorbital pain, } \\
\text { diplopia } \\
n=1\end{array}$ \\
\hline $\begin{array}{l}\text { Phylactou et al. [47] } \\
\text { Characteristics of endothelial } \\
\text { corneal transplant rejection } \\
\text { following immunization } \\
\text { with SARS-CoV-2 } \\
\text { messenger RNA vaccine }\end{array}$ & $\begin{array}{l}\text { A case report of Descemet } \\
\text { membrane endothelial } \\
\text { keratoplasty (DMEK) } \\
\text { patients with graft } \\
\text { rejection post-vaccination }\end{array}$ & BNT162b2 & 7 days to 3 weeks & $\begin{array}{l}\text { Blurred vision, red } \\
\text { eye, photophobia } \\
n=2\end{array}$ \\
\hline
\end{tabular}


Table 1 continued

\begin{tabular}{|c|c|c|c|c|}
\hline$\overline{\text { Study }}$ & Summary & $\begin{array}{l}\text { Vaccine } \\
\text { studied }\end{array}$ & $\begin{array}{l}\text { Time to onset of } \\
\text { symptoms }\end{array}$ & $\begin{array}{l}\text { Ocular symptoms } \\
\text { and number of cases } \\
(n)\end{array}$ \\
\hline $\begin{array}{l}\text { Wasser et al. [48] } \\
\text { Keratoplasty Rejection After } \\
\text { the BNT162b2 messenger } \\
\text { RNA vaccine }\end{array}$ & $\begin{array}{l}\text { A case report of penetrating } \\
\text { keratoplasty (PKP) } \\
\text { patients with graft } \\
\text { rejection post-vaccination }\end{array}$ & BNT162b2 & 13-14 days & $\begin{array}{l}\text { Blurred vision, ocular } \\
\text { discomfort, red eye } \\
n=2\end{array}$ \\
\hline $\begin{array}{l}\text { Ravichandran et al. [49] } \\
\text { Corneal graft rejection after } \\
\text { COVID-19 vaccination }\end{array}$ & $\begin{array}{l}\text { A case report of PKP patient } \\
\text { with graft rejection post- } \\
\text { vaccination }\end{array}$ & AZD1222 & 3 weeks & $\begin{array}{l}\text { Blurred vision, red } \\
\text { eye } \\
n=1\end{array}$ \\
\hline $\begin{array}{l}\text { Bøhler et al. [45] } \\
\text { Acute macular } \\
\text { neuroretinopathy following } \\
\text { COVID-19 vaccination }\end{array}$ & $\begin{array}{l}\text { A case report of acute } \\
\text { macular neuroretinopathy } \\
(A M N) \text { post-vaccination }\end{array}$ & AZD1222 & 2 days & $\begin{array}{l}\text { Paracentral scotoma } \\
n=1\end{array}$ \\
\hline $\begin{array}{l}\text { Mambretti et al. [44] } \\
\text { Acute macular } \\
\text { neuroretinopathy following } \\
\text { coronavirus disease } 2019 \\
\text { vaccination }\end{array}$ & $\begin{array}{l}\text { A case report of acute } \\
\text { macular neuroretinopathy } \\
(\text { AMN) post-vaccination }\end{array}$ & AZD1222 & 2 days & $\begin{array}{l}\text { Paracentral scotoma } \\
n=2\end{array}$ \\
\hline $\begin{array}{l}\text { Michel et al. }[43] \\
\text { Acute macular } \\
\text { neuroretinopathy after } \\
\text { COVID-19 vaccine }\end{array}$ & $\begin{array}{l}\text { A case report of acute } \\
\text { macular neuroretinopathy } \\
(A M N) \text { post-vaccination }\end{array}$ & AZD1222 & 2 days & $\begin{array}{l}\text { Central scotoma } \\
n=1\end{array}$ \\
\hline $\begin{array}{l}\text { Santovito et al. [52] } \\
\text { Acute reduction of visual } \\
\text { acuity and visual field after } \\
\text { Pfizer-BioNTech COVID- } \\
19 \text { vaccine 2nd dose: a case } \\
\text { report }\end{array}$ & $\begin{array}{l}\text { A case report of possible } \\
\text { uveitis post-vaccination }\end{array}$ & BNT162b2 & 3 days & $\begin{array}{l}\text { Reduction in visual } \\
\text { acuity, visual } \\
\text { distortion } \\
n=1\end{array}$ \\
\hline $\begin{array}{l}\text { Mudie et al. [53] } \\
\text { Panuveitis following } \\
\text { vaccination for COVID-19 }\end{array}$ & $\begin{array}{l}\text { A case report of panuveitis } \\
\text { post-vaccination }\end{array}$ & BNT162b2 & 3 days & $\begin{array}{l}\text { Reduction in visual } \\
\text { acuity, ocular pain, } \\
\text { red eye, } \\
\text { photophobia } \\
n=1\end{array}$ \\
\hline $\begin{array}{l}\text { Reyes-Capo et al. [54] } \\
\text { Acute abducens nerve palsy } \\
\text { following COVID-19 } \\
\text { vaccination }\end{array}$ & $\begin{array}{l}\text { A case report of isolated } \\
\text { abducens nerve palsy post- } \\
\text { vaccination }\end{array}$ & BNT162b2 & 2 days & $\begin{array}{l}\text { Painless, horizontal, } \\
\text { binocular diplopia } \\
n=1\end{array}$ \\
\hline
\end{tabular}


Table 1 continued

\begin{tabular}{|c|c|c|c|c|}
\hline$\overline{\text { Study }}$ & Summary & $\begin{array}{l}\text { Vaccine } \\
\text { studied }\end{array}$ & $\begin{array}{l}\text { Time to onset of } \\
\text { symptoms }\end{array}$ & $\begin{array}{l}\text { Ocular symptoms } \\
\text { and number of cases } \\
\text { (n) }\end{array}$ \\
\hline $\begin{array}{l}\text { Fowler et al. [55] } \\
\text { Acute-onset central serous } \\
\text { retinopathy after } \\
\text { immunization with } \\
\text { COVID-19 mRNA vaccine }\end{array}$ & $\begin{array}{l}\text { A case report of acute-onset } \\
\text { central serous retinopathy } \\
\text { (CSR) post-vaccination }\end{array}$ & BNT162b2 & 3 days & $\begin{array}{l}\text { Blurring of vision, } \\
\text { metamorphopsia } \\
n=1\end{array}$ \\
\hline $\begin{array}{l}\text { Papasavvas et al. [40] } \\
\text { Reactivation of Vogt- } \\
\text { Koyanagi-Harada disease } \\
\text { under control for }>6 \text { years, } \\
\text { following anti-SARS-CoV- } \\
2 \text { vaccination }\end{array}$ & $\begin{array}{l}\text { A case report of reactivation } \\
\text { of Vogt-Koyanagi-Harada } \\
\text { disease post-vaccination }\end{array}$ & BNT162b2 & 6 weeks & $\begin{array}{l}\text { Photophobia, ocular } \\
\text { pain } \\
n=1\end{array}$ \\
\hline $\begin{array}{l}\text { Vera-Lastra et al. [59] } \\
\text { Two cases of Graves' disease } \\
\text { following SARS-CoV-2 } \\
\text { vaccination: an } \\
\text { autoimmune/inflammatory } \\
\text { syndrome induced by } \\
\text { adjuvants }\end{array}$ & $\begin{array}{l}\text { A case report of Graves' } \\
\text { disease activation post- } \\
\text { vaccination }\end{array}$ & BNT162b2 & 2-3 days & $\mathrm{NA}$ \\
\hline $\begin{array}{l}\text { Bialasiewicz et al. [56] } \\
\text { Central retinal vein } \\
\text { occlusion occurring } \\
\text { immediately after } 2 \text { nd dose } \\
\text { of mRNA SARS-CoV-2 } \\
\text { vaccine }\end{array}$ & $\begin{array}{l}\text { A case report of central } \\
\text { retinal vein occlusion post- } \\
\text { vaccination }\end{array}$ & $\mathrm{BNT} 162 \mathrm{~b} 2$ & $15 \mathrm{~min}$ & $\begin{array}{l}\text { Retrobulbar pain, red } \\
\text { eye and vision } \\
\text { reduction } \\
n=1\end{array}$ \\
\hline $\begin{array}{l}\text { Valenzuela et al. [46] } \\
\text { Acute macular } \\
\text { neuroretinopathy following } \\
\text { Pfizer-BioNTech COVID- } \\
19 \text { vaccination }\end{array}$ & $\begin{array}{l}\text { A case report of acute } \\
\text { macular neuroretinopathy } \\
\text { post-vaccination }\end{array}$ & BNT162b2 & $48 \mathrm{~h}$ & $\begin{array}{l}\text { Paracentral scotoma } \\
n=1\end{array}$ \\
\hline $\begin{array}{l}\text { Leber et al. [58] } \\
\text { Acute thyroiditis and } \\
\text { bilateral optic neuritis } \\
\text { following SARS-CoV-2 } \\
\text { vaccination with } \\
\text { CoronaVac: a case report }\end{array}$ & $\begin{array}{l}\text { A case report of bilateral } \\
\text { optic neuritis post- } \\
\text { vaccination }\end{array}$ & PiCoVacc & $12 \mathrm{~h}$ & $\begin{array}{l}\text { Rapidly progressive } \\
\text { low visual acuity } \\
\text { and pain on } \\
\text { movement of the } \\
\text { left eye and } \\
\text { headache } \\
n=1\end{array}$ \\
\hline
\end{tabular}


Table 1 continued

\begin{tabular}{|c|c|c|c|c|}
\hline Study & Summary & $\begin{array}{l}\text { Vaccine } \\
\text { studied }\end{array}$ & $\begin{array}{l}\text { Time to onset of } \\
\text { symptoms }\end{array}$ & $\begin{array}{l}\text { Ocular symptoms } \\
\text { and number of cases } \\
\text { (n) }\end{array}$ \\
\hline $\begin{array}{l}\text { El Sheikh et al. [42] } \\
\text { Acute uveitis following } \\
\text { COVID-19 vaccination }\end{array}$ & $\begin{array}{l}\text { A case report of juvenile } \\
\text { idiopathic arthritis (JIA)- } \\
\text { associated anterior uveitis } \\
\text { post-vaccination }\end{array}$ & BBIBP-CorV & 5 days & $\begin{array}{l}\text { Acute onset of } \\
\text { bilateral blurred } \\
\text { vision and } \\
\text { photophobia } \\
n=1\end{array}$ \\
\hline $\begin{array}{l}\text { Goyal et al. [57] } \\
\text { Bilateral multifocal } \\
\text { choroiditis following } \\
\text { COVID-19 vaccination }\end{array}$ & $\begin{array}{l}\text { A case report of bilateral } \\
\text { choroiditis following } \\
\text { COVID-19 vaccination }\end{array}$ & AZD1222 & $24 \mathrm{~h}$ & $\begin{array}{l}\text { Ocular pain, eye } \\
\text { redness, floaters, } \\
\text { severe vision loss } \\
n=1\end{array}$ \\
\hline $\begin{array}{l}\text { Ish et al. [38] } \\
\text { Facial nerve palsy after } \\
\text { COVID-19 vaccination-a } \\
\text { rare association or a } \\
\text { coincidence }\end{array}$ & $\begin{array}{l}\text { A case report of facial nerve } \\
\text { palsy following COVID- } \\
19 \text { vaccination }\end{array}$ & BBV152 & 21 days & $\begin{array}{l}\text { Difficulty in closing } \\
\text { the right eye } \\
\text { associated with } \\
\text { redness and } \\
\text { watering } \\
n=1\end{array}$ \\
\hline $\begin{array}{l}\text { Rallis et al. [50] } \\
\text { Corneal graft rejection } \\
\text { following COVID-19 } \\
\text { vaccine }\end{array}$ & $\begin{array}{l}\text { A case report of corneal graft } \\
\text { rejection following } \\
\text { COVID-19 vaccination }\end{array}$ & BNT162b2 & 4 days & $\begin{array}{l}\text { Painful red eye and } \\
\text { rapid deterioration } \\
\text { of vision } \\
n=1\end{array}$ \\
\hline $\begin{array}{l}\text { Pichi et al. [51] } \\
\text { Association of ocular adverse } \\
\text { events with inactivated } \\
\text { COVID-19 vaccination in } \\
\text { patients in Abu Dhabi }\end{array}$ & $\begin{array}{l}\text { A case series of patients } \\
\text { presenting to a tertiary } \\
\text { center with ocular adverse } \\
\text { events within } 15 \text { days post- } \\
\text { vaccination }\end{array}$ & BBIBP-CorV & $\begin{array}{l}1-10 \text { days } \\
\quad(\text { mean }=5.2 \text { days })\end{array}$ & $\begin{array}{l}\text { NA } \\
n=7\end{array}$ \\
\hline $\begin{array}{l}\text { Koong et al. [41] } \\
\text { Vogt-Koyanagi-Harada } \\
\text { disease associated with } \\
\text { COVID-19 mRNA vaccine }\end{array}$ & $\begin{array}{l}\text { A case report of a patient } \\
\text { presenting with Vogt- } \\
\text { Koyanagi-Harada disease } \\
5 \text { days post-vaccination }\end{array}$ & BNT162b2 & 5 days & $\begin{array}{l}\text { NA } \\
n=1\end{array}$ \\
\hline $\begin{array}{l}\text { Unpublished data from } \\
\text { authors }\end{array}$ & $\begin{array}{l}\text { A case series of patients } \\
\text { presenting to tertiary } \\
\text { centers with ocular } \\
\text { inflammation within } 6 \\
\text { weeks post-vaccination }\end{array}$ & $\begin{array}{l}\text { BNT162b2, } \\
\text { mRNA- } \\
1273 \\
\text { Sinovac }\end{array}$ & 1 day to 6 weeks & $\begin{array}{l}\text { NA } \\
n=17\end{array}$ \\
\hline
\end{tabular}




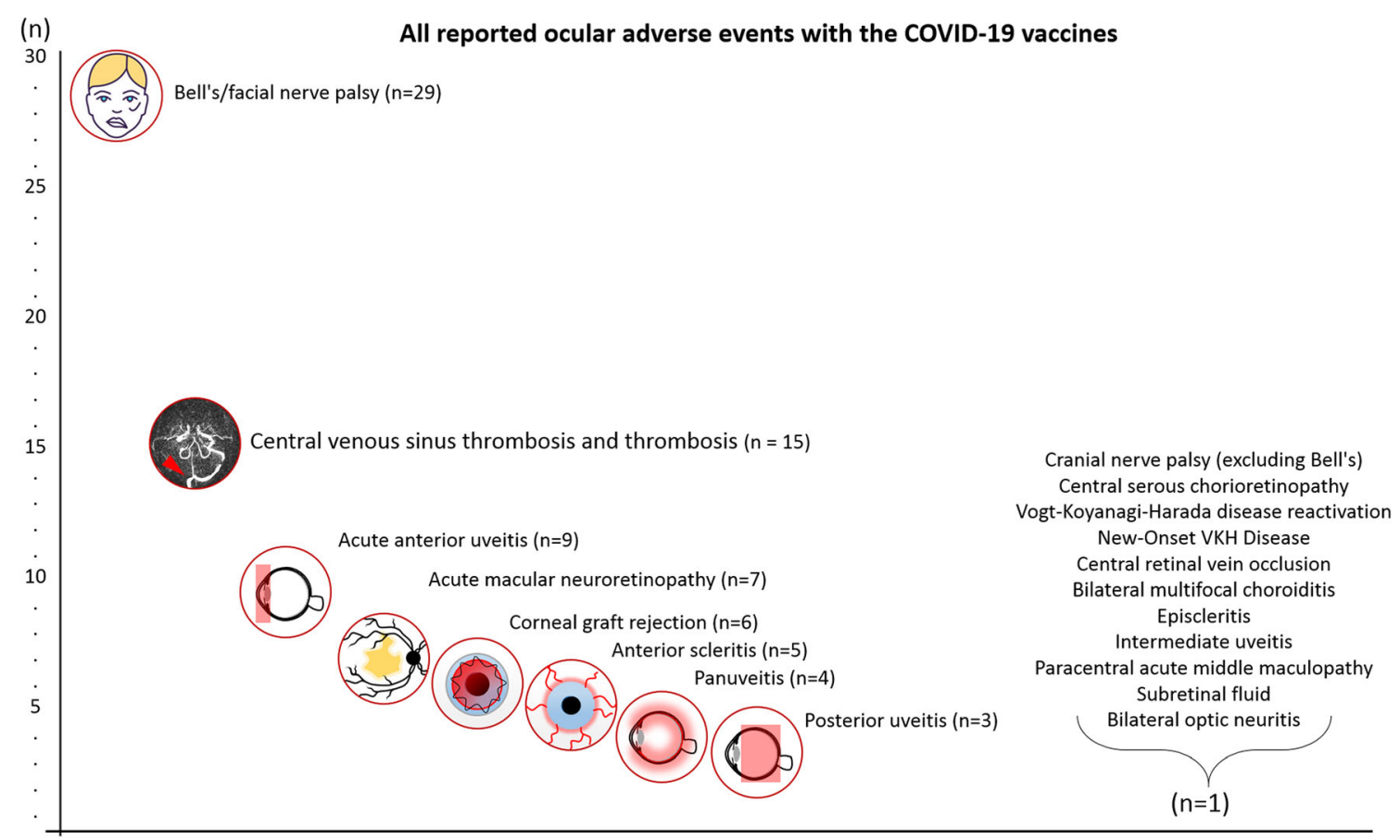

Fig. 1 Diagrammatic representation of the total number of subjects and different clinical presentations for post-COVID-19 vaccination ocular adverse events

\section{Bell's/Facial Nerve Palsy}

One study, part of the clinical trials for the BNT162b2 and mRNA-1273 vaccines, found a higher incidence of Bell's palsy in subjects receiving the vaccine $(n=7)$ than in those receiving placebo $(n=1)$ [36]. The time to the onset of symptoms was not mentioned. A casecontrol study found that in 21 patients against 44 unvaccinated controls who presented with facial nerve palsy and had received the BNT162b2 vaccine (first or second dose) 30 days prior, there was no significant difference in the occurrence of facial nerve palsy [37]. However, both studies did not include any details on ocular manifestations or ophthalmic investigations, nor did they provide visual outcomes of the patients. Another case report by Ish et al. reported a middle-aged male who developed facial nerve palsy 3 weeks after receiving the second dose of COVAXIN [38]. He was treated with a tapering dose of oral prednisolone at $1 \mathrm{mg} / \mathrm{kg}$ for 2 weeks with improvement of presentation on review at day 10 .

\section{Superior Ophthalmic Vein Thrombosis}

There is a published report of two patients with bilateral thrombosis of the superior ophthalmic vein in addition to rare cases of cerebral venous sinus thrombosis and vaccine-induced immune thrombocytopenia with consequential orbital symptoms and signs of inflammation [39-41]. Investigations performed to confirm thrombosis include computed tomography (CT), angiography of the head and neck and magnetic resonance imaging (MRI) of the brain. Of the 15 subjects with thrombosis reported in these three studies, 4 presented with ocular symptoms including conjunctival congestion, fixed and dilated pupil, gaze deviation, diplopia, retroorbital pain and unspecified visual changes. All four were female; two had additional risk factors for thrombosis, including obesity, hypothyroidism and oral contraceptive pill (OCP) usage. The subjects manifested symptoms between 6 and 17 days post-vaccination. Subjects received either the AZD1222 or Ad26COVS1 vaccines. Of note, the Ad26COVS1 was designed as a singledose vaccine. None included detailed 
ophthalmic investigations, treatment, or visual outcomes of the subjects.

\section{Acute Anterior Uveitis}

Our local authors (unpublished data) reported seven cases of acute anterior non-granulomatous uveitis post-vaccination. Symptom onset ranged from 1 day to 1 month after receiving the first or second dose of the BNT162b2 or mRNA-1273 vaccine. Similarly, El Sheikh et al. reported one cases of acute uveitis following vaccination with the BBIBP-CorV vaccine [42]. The female subject presented 5 days following the second dose of the vaccine with acute onset of bilateral blurred vision and photophobia and was diagnosed with juvenile idiopathic arthritis (JIA)-associated anterior uveitis that responded to topical corticosteroid treatment.

\section{Acute Macular Neuroretinopathy (AMN)}

Four female subjects presented with scotomas. All were on oral contraceptive pills (OCP) and manifested symptoms 2 days after the first dose of the vaccine [43-45]. Three reported fever, and one reported flu-like symptoms prior to the appearance of the scotoma. In two patients, the visual symptoms lasted $<24 \mathrm{~h}$. On OCT, hyperreflectivity of the outer nuclear and plexiform layers was seen along with disruption of the ellipsoid zone. Subtle capillary dropout was also noted on angiography. All subjects received the AZD1222 vaccine. In another case report, Valenzuela et al. reported a case of a young female subject who presented with bilateral scotoma and photopsia $48 \mathrm{~h}$ after receiving the second dose of the BNT162b2 vaccine [46]. The subject was using an etonogestrel/ethinyl estradiol $0.12-0.015 \mathrm{mg} / 24 \mathrm{~h}$ vaginal ring for birth control. OCT demonstrated parafoveal foci of hyperreflectivity of the outer nuclear layer and granularity of the ellipsoid. Her symptoms resolved completely a week later.

\section{Corneal Graft Rejection}

There were two reported cases of allograft rejection following Descemet's membrane endothelial keratoplasty (DMEK); both were female and had had grafts performed 21 days and 6 years before vaccine administration [47]. With a notable history of well-controlled human immunodeficiency virus infection with undetectable viral load, one subject manifested symptoms 7 days after the first dose of the vaccine. The other patient developed symptoms 3 weeks after the second dose. For both DMEK cases, slit-lamp examination and anterior optical coherence tomography (OCT) revealed moderate conjunctival injection, diffuse corneal edema and fine keratic precipitates limited to the donor endothelium with anterior chamber cells. Rejections were also reported following three penetrating keratoplasty (PKP) cases; all three were male; 1 case had a previous regraft. Two of the PKP rejections manifested 13-14 days after the patients received the first dose of the vaccine, while the third occurred after 21 days, also from the first dose [48, 49]. The two DMEK and two of the three PKP rejections were treated successfully with oral and topical corticosteroids. Vaccines received by the subjects included the BNT162b2 and AZD1222 vaccines. In addition, Rallis et al. reported a case of a 68-year-old female subject who presented with left eye corneal graft failure 4 days after receiving the first dose of the BNT162b2 vaccine [50]. She had a history of bilateral Descemet stripping automated endothelial keratoplasty (DSAEK) for Fuchs' corneal endothelial dystrophy and a left repeat penetrating keratoplasty (PKP) for failed DSAEK in October 2020. Slitlamp examination revealed conjunctival hyperemia, corneal graft edema, diffuse corneal punctate staining, Descemet's folds, scattered keratic precipitates and anterior chamber activity. Her right eye graft remained healthy. She was treated with intensive topical corticosteroids to her left eye and oral acyclovir to cover any underlying herpetic keratitis. Graft rejection resolved completely 3 weeks posttreatment.

\section{Anterior Sclerites}

Several cases of post-vaccination anterior scleritis have been reported. From our unpublished 
data, there have been three cases of diffuse anterior non-necrotizing anterior uveitis in female subjects 1 to 4 days after receiving the second dose of BNT162b2. The subjects' symptomatic decrease in visual acuity resolved after receiving topical corticosteroids and additional oral NSAIDs in one subject. Pichi et al. reported two cases of anterior scleritis after receiving the BBIBP-CorV vaccine [51]. One patient presented with pain and redness in both eyes 1 week after receiving a dose of the vaccine, which resolved after a tapering dose of topical steroids.

\section{Panuveitis}

Several case reports were identified. The first case was of a male patient with a prior SARSCOV-2 infection several months earlier who developed transient visual field loss 3 days after a first dose of BNT162b2 [52]. The visual acuity deficit lasted less than a day and was associated with perceived reduction of visual fields, a unilateral headache, nausea, asthenia and mild confusion. There was no further investigation. The second case concerned a female subject who on examination was found to have panuveitis [53]. She developed symptoms 3 days after the second dose. She underwent weekly nasopharyngeal swab tests for COVID-19 infection as part of her occupation's routine required testing, of which only one was positive, with subsequent tests being negative. She neither manifested any symptoms of COVID-19 nor had a history of exposure to COVID-19 patients. Her vision of 20/500 in both eyes improved to $20 / 20$ on a tapering dose of systemic corticosteroids, starting at $50 \mathrm{mg} /$ day of oral prednisone and 2 hourly difluprednate lasting 3 weeks. At the end of 3 weeks, there was recurrence of choroidal thickening, and systemic corticosteroid therapy was recommenced at the time of publication. OCT was performed, which showed vitreous debris and retinal and choroidal thickening. Fluorescein angiography (FA) revealed mild peripheral vascular leakage. MRI brain and orbits with contrast were unremarkable. Both subjects had received the BNT162b2 vaccine.

\section{Posterior Uveitis}

Two female subjects presented to a local institution in Singapore (unpublished data) with posterior uveitis 3-6 weeks after receiving the second dose of BNT162b2. One subject presented with a scotoma and photopsia in the left eye while the other was found to have retinal dysfunction and papillitis. Their symptoms resolved upon receiving corticosteroids. One male patient also presented with decreased visual acuity 7 days after receiving the first dose of mRNA-1273, which was diagnosed as posterior uveitis. His symptoms resolved after the administration of oral and topical corticosteroids.

\section{Cranial Nerve Palsy (Excluding Bell's/ Facial Nerve Palsy)}

A healthy female who received the BNT162b2 vaccine and presented with isolated abducens nerve palsy 2 days post-vaccination was reported [54]. No details on the persistence of the palsy were provided in the report. Examinations of the patient through slit-lamp, fundus examination and MRI brain and orbits without contrast were unremarkable.

\section{Central Serous Retinopathy}

Sixty-nine hours after receiving the first dose of the BNT162b2 vaccine, a 33-year-old male subject with a previous history of mild refractive hyperopic refractive error presented with blurring of vision and metamorphopsia and was subsequently diagnosed with central serous retinopathy [55]. Fundus examination revealed loss of foveal reflex and a swollen macula without hemorrhage. Further investigations such as imaging were performed. OCT revealed macular serous detachment of the neurosensory retina. In the area of serous retinal detachment, OCT angiography showed general attenuation of choriocapillaris flow signal while FA showed point leakage. After a course of spironolactone, all the patients' symptoms resolved on followup. 


\section{Vogt-Koyanagi-Harada (VKH)}

A female patient with a 6-year history of wellcontrolled VKH presented with a severe reactivation of VKH 6 weeks after receiving the second dose of the BNT162b2 vaccine. The initial onset of her VKH had been severe, which necessitated infliximab infusions as acute and maintenance therapy. Prior to the vaccinations, the patient had received infliximab infusions 3.5 weeks before the first vaccine dose and 7.5 weeks before the second vaccine dose [40]. Slit-lamp examination revealed anterior chamber inflammation with mutton-fat keratic precipitates. Furthermore, retinal folds, subretinal fluid and increased choroidal thickness were seen on OCT imaging. After the initiation of oral corticosteroids and infliximab therapy, the $\mathrm{VKH}$ disease reactivation was controlled. In a separate report, a 54-year-old male patient with no history of ocular disease presented with acute bilateral painless blurring of vision a week after receiving the first dose of the BNT162b2 vaccine. Clinical examination and imaging investigations were consistent with and led to the diagnosis of Vogt-Koyanagi-Harada disease. After an initial course of high-dose intravenous methylprednisolone and subsequent oral prednisolone, the patient's symptoms resolved [41].

\section{Central Retinal Vein Occlusion}

Bialasiewicz et al. reported a case of central retinal vein occlusion post-vaccination in an otherwise previously healthy 50 -year-old male patient [56]. During the 15-min surveillance period after receiving the second dose of BNT162b2, the patient developed retrobulbar pain, red eye and decreased vision in his left eye, which was eventually found to be caused by a central retinal vein occlusion. Investigations that were done, such as a thrombophilia panel, complete blood count and D-dimer levels, were unremarkable.

\section{Bilateral Multifocal Choroiditis}

Goyal et al. reported a case of bilateral choroiditis in a 34-year-old male patient post- vaccination [57]. One week after the second dose of AZD1222, the patient presented with severe vision loss of his right eye. Examination revealed a large serous detachment of the macula of the right eye. Additionally, ultrasonographic evaluation showed choroidal thickening in both eyes. After completing a 2-week course of oral corticosteroids, the patient made complete visual recovery.

\section{Episcleritis}

Pichi et al. reported a case of episcleritis in a patient who had previously received the BBIBPCorV vaccine. However, further details of the case were not reported [51].

\section{Intermediate Uveitis}

Our authors have seen a case of intermediate uveitis in a 50-year-old female patient following vaccination. Nine days after receiving the first dose of BNT162b2, the patient experienced an exacerbation of her existing intermediate uveitis complicated by cystoid macular edema.

\section{Paracentral Acute Middle Maculopathy}

A case of paracentral acute middle maculopathy was reported by Pichi et al. [51]. Twenty minutes after receiving the BBIBP-CorV vaccine, the patient had developed tachycardia, raised systolic blood pressure and an inferior scotoma of the left eye. Fundus examination revealed a dot hemorrhage superior to the fovea, and OCT angiography revealed superior enlargement of the foveal avascular zone.

\section{Subretinal Fluid}

Pichi et al. reported a case of subretinal fluid in a patient who had previously received the BBIBPCorV vaccine. However, further details of the case were not reported [48]. 


\section{Bilateral Optic Neuritis}

A case of acute thyroiditis and bilateral optic neuritis following vaccination was reported by Leber et al. [58]. Twelve hours after receiving the second dose of PiCoVacc, a 32-year-old female experienced rapidly progressive decreased visual acuity, pain on movement of the left eye and headache. Furthermore, the patient experienced loss of temporal visual field of the left eye. Best corrected visual acuity was found to be 20/200 in the left eye, while this was preserved at 20/20 in the right eye. Fundus examination revealed bilateral disc swelling that was more prominent in the left eye. Subsequent work-up for raised intracranial pressure, demyelinating disease, intracranial infection and inflammatory disease was unremarkable. The patient was then diagnosed with vaccination-related bilateral optic neuritis and treated with intravenous corticosteroids, with subsequent improvement in visual acuity.

\section{Graves' Disease}

Two cases of Graves' disease (GD) post-vaccination were reported. One patient had a past medical history of a prior COVID-19 infection and pulmonary arterial hypertension. Both patients received the first dose of the BNT162b2 vaccine and reported their symptoms 2 to 3 days after and were subsequently diagnosed with Graves' disease [59]. Biochemical studies including thyrotropin (TSH), thyroxine and triiodothyronine, antithyroid peroxidase, antithyroglobulin, anti-TSH and anti-TSH antibodies were performed, and the tests indicated active GD. The study did not include any description of ocular symptoms or ophthalmic investigations. Both patients' presentations fit the diagnostic criteria for autoimmune/ inflammatory syndrome induced by adjuvants (ASIA), which is also known as Shoenfeld's syndrome[28, 60].

\section{POSSIBLE MECHANISTIC INSIGHTS AND IMPACT}

To increase the magnitude and efficacy of vaccines, adjuvants are added, which are meant to potentiate vaccine-mediated immune responses. While adjuvants are generally efficacious and safe, the administration of adjuvants may lead to autoimmune/inflammatory syndrome in a fraction of predisposed or genetically susceptible individuals (Fig. 2). According to WHO, about 185 COVID-19 vaccines are being explored in laboratory experiments and in animal models. About 114 vaccines are at various stages of Phase I-IV clinical trials. With extensive worldwide vaccination programs, few adverse events have been reported thus far. At present, there are four different types of COVID19 vaccines. All four classes of COVID-19 vaccines have been under various stages of clinical trial (summarized in Fig. 3).

Vaccine-associated uveitis (VAU) have been reported with almost all vaccines to date: hepatitis $B$ vaccine, HPV vaccine, influenza vaccine, BCG vaccine, measles, mumps and rubella (MMR) and varicella vaccine [61]. Apart from reaction to adjuvants, molecular mimicry between vaccine peptide fragments and uveal self-peptides and delayed hypersensitivity, leading to deposition of immune complexes, have been suggested as possible reasons for VAU [62]. Furthermore, possible antigenic mimicry of Spike protein with retinal peptides cannot be ruled out.

Since administered vaccines are not able to cause the disease in the recipient but can still induce an immune response against the infection, we hypothesize that ocular events postCOVID-19 vaccination involve an altered metabolism of RNA (Spike protein) in susceptible individuals and the induction of TLRs.

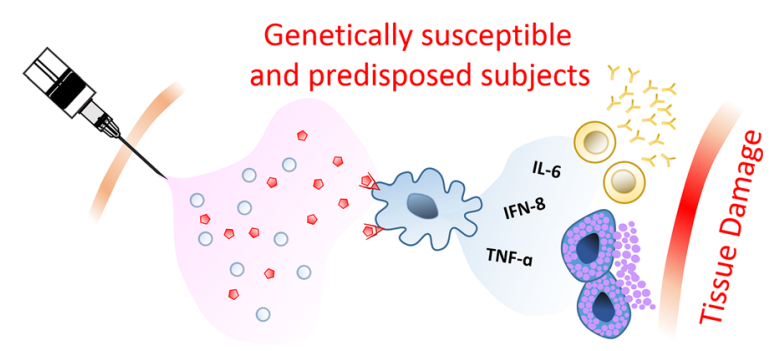

Fig. 2 A possible hypothesis for post COVID-19 vaccination-associated ocular inflammation: illustration of the potential role of adjuvants in post-vaccination inflammation in genetically susceptible and predisposed subjects 


\section{Nucleic acid}

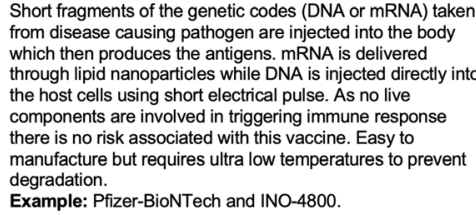

Short fragments of the genetic codes (DNA or mRNA) taken from disease causing pathogen are injected into the body which then produces the antigens. MRNA is delivered the host cells using short electrical pulse. As no live components are involved in triggering immune response there is no risk associated with this vaccine. Easy to manufacture but requires ultra low temperatures to prevent degradation. Example: Pfizer-BioNTech and INO-4800.

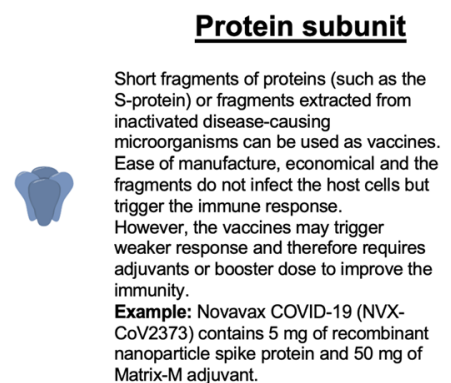

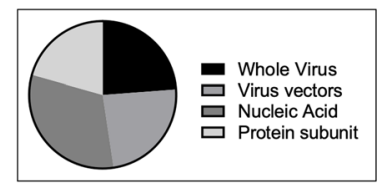
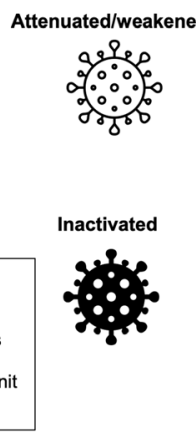

Whole virus

Virus is weakened by passing the disease-causing virus through animals/human cells until new 'weakened variant is formed. The modified microorganism replicates and provokes immune response without causing illness. This type of vaccines are effective with single dose. The vaccines are sensitive to light and heat, therefore, stored carefully. Vaccines may cause adverse immune response in immune-deficient patients. Example: COVI-VAC from Codagenix

Inactivated vaccines are produced by growing the disease causing virus in a culture media followed by inactivation through heat or chemicals. This type of vaccines do not cause adverse effect even in immuno-deficient patients since the vaccine contents do not replicate. The process requires large quantities of infectious viruses. Inactivated vaccines provoke immune response by humoral, therefore, requires multiple doses.

Example: CoronaVac from Sinovac Biotech

\section{Viral vector}

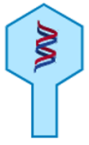

Use of non-replicating (adenoviruses/poxviruses) or replicating (measles/vesicular stomatitis) as a carrier for genetic codes of disease-causing pathogen. Induce The vaccines are well tolerated and highly immunogenic but requires booster shots to induce long-term immunity. Example: Ad5-nCoV and Ad26COVS1. robust cell mediated immunity in addition to antibodies.

Fig. 3 Pie chart showing the development of COVID-19 vaccines at various stages (Phase I-III) of clinical trials (as of January 2021) and their classifications

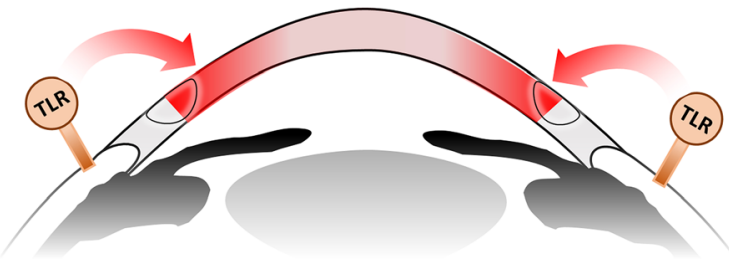

Fig. 4 Illustration of the possible path/mechanism of corneal graft rejection post-COVID-19 vaccination

Regarding COVID-19 vaccination-induced corneal graft rejection, the induction of TLRs in murine models demonstrates a contribution to corneal graft rejection via Th1 immunity [63]. With persistence of RNA in susceptible individuals, TLRs on the ocular surface are activated, which may contribute to the rejection of allogeneic grafts (Fig. 4). We suggest considering closer follow-up of corneal graft patients post-vaccination to allow for monitoring of graft health and the institution of earlier treatment in the event of rejection. The role of prophylactic corticosteroids may be appraised as well. This would serve to reduce the chance of graft loss and poorer visual outcomes, though it must be balanced against the side effects of systemic corticosteroid usage. In this time of the pandemic, rescheduling of nonurgent corneal graft surgery may also be considered.

$A M N$ is a rare retinal disease, the pathophysiology of which is still unknown, although a microvascular abnormality in the deep capillary plexus of the retina is hypothesized. Of the AMN cases reviewed, all four subjects had the confounder of OCP usage. However, the relative rarity of $\mathrm{AMN}$ and the temporal association between the vaccine administration and onset of the disease should be considered. OCP usage has been associated with structural changes to the macula, retinal nerve fiber layer and choroidal thickness [64] and identified as a risk factor for AMN. This is likely due to the presence of estrogen and progesterone receptors in ocular tissues of premenopausal women, including the choroid and retina [65]. It has been postulated that concurrent OCP usage may increase the susceptibility of ocular tissues to AMN. Whether the potential thrombogenic role of COVID-19 vaccination played an additional role in the AMN pathogenesis of these patients has yet to be established (Fig. 5).

Regarding uveitis, it is interesting to note a similar timeline between the presentation of the case report mentioned above and that of a confirmed COVID-19 infected patient [10]. Of 


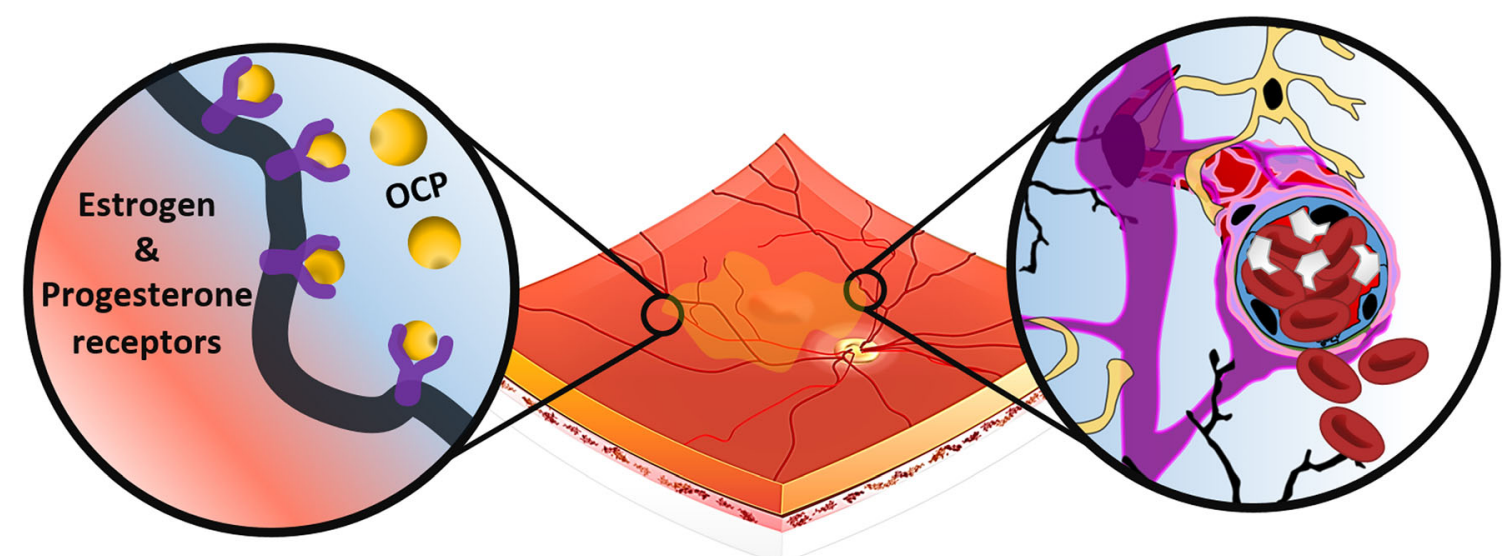

Fig. 5 Illustration of onset of acute macular neuroretinopathy following COVID-19 vaccination—a possible mechanism

note, both the post-vaccination and the infected cases presented acutely within 2 weeks. Furthermore, bilateral anterior uveitis as a component of a multisystem inflammatory response to COVID-19 has been reported as well as a COVID-19 patient presenting with VKH $[66,67]$. This lends credence to the theory that the inflammation is secondary to the innate immune response and that susceptible individuals may have altered RNA metabolism and overactivity of TLRs (as in $\mathrm{VKH}$ ) that is triggered by the virus or the vaccine [59].

Concerning CSVT and thrombosis cases, we suggest a closer review of the temporal relation between the vaccine administration and ocular thromboembolic pathology, for instance, with retinal vein occlusion (RVO). RVO has been reported in previously healthy COVID-19 patients [68]. With the establishment of VITT, it would not be surprising if more reports on ocular thromboembolic phenomena are written in the future.

Patients with autoimmune disease (AID) are in a pro-inflammatory state with a predisposition to ocular inflammation such as retinitis and maculopathy [69]. We have included the report on Graves' disease above for this purpose, especially as Graves' is known to be associated with ophthalmopathy, which may be the first clinical presentation of the disease. Proposed mechanisms that contribute to AID flares postvaccination include molecular mimicry, direct inflammatory insult, deposition of immune- complement complexes because of vaccine adjuvants (as with ASIA) and antigenic crossreactivity [70-73]. As described in the introduction, the abnormal metabolism of RNA and induction of TLRs in susceptible individuals should also be considered. As more information is revealed about the details of the mechanisms involved, we hope that susceptible populations may be identified and preemptively screened. Consideration should also be given to Graves' disease patients post-vaccination, with the advice given to monitor for reactivation of the disease. Patient education and collaboration between the primary endocrinologist/physician and the ophthalmologist involved in managing a patient's Graves' disease are crucial for early detection of signs and symptoms and early treatment. As with corneal graft patients, a review on prophylactic treatment might be beneficial for patients.

A corollary to consider is vaccine response in patients with autoimmune disease [73]. Vaccinations in the autoimmune population decrease the burden of infection. However, with the above, the consequences of maladaptive immune response in those with autoimmune disease resulting in reactivation of disease (as with VKH) should be considered. It is then essential to establish the response of autoimmune disease patients to vaccines and whether the response is suboptimal in this population. This would have far-reaching consequences for 
future development of vaccines and risk stratification of at-risk groups.

We would like to acknowledge limitations in the review above. This article represents an effort to consolidate reported vaccine-associated adverse ocular events to date. As such, the inclusion criteria are numerous to capture an overview of the variety in presentation regarding ocular adverse events associated with vaccination that may first present to the ophthalmic setting. With variations in availability of vaccines, international approaches to vaccination campaigns and the nature of the studies reviewed-mostly case reports-there is significant heterogeneity in terms of assessment of patients and consolidation of cases deemed related to COVID-19 vaccination. In this article, we propose that certain individuals are genetically predisposed to vaccine-induced ocular adverse events. It is our hope that the article will serve as a springboard for more refined and standardized investigations regarding adverse ocular events post-vaccination.

\section{CONCLUSION}

The COVID-19 vaccines discussed in this review are relatively new. Much of the reviewed literature consisted of case reports and case series. Many reports provided limited details regarding ophthalmic examination, imaging, treatment and visual outcomes of patients. Notwithstanding the variation in details, such case reports represent possible ocular side effects associated with COVID-19 vaccines. More data on their side effects are emerging each day, and our knowledge on these side effects is still expanding. Given the nascent nature of these vaccines, we are unable to establish any causality in this review. Moreover, most cases of ocular side effects post-vaccination that were reviewed in this article saw swift recovery following the initiation of treatment. It is worth drawing attention to the fact that these adverse events related to COVID-19 vaccines have a remarkably low incidence. This is especially so when considering the extremely large numbers of people that have been inoculated around the world. Currently, there is no evidence to suggest that any special ophthalmic population has contraindications to vaccination.

This review article precedes a multicenter study on possible ocular associations postCOVID-19 vaccination, and we will eventually be looking at potential biomarkers associated with intraocular inflammation in correlation with COVID-19 vaccination. Implementation of a dedicated ophthalmic registry or establishing an ophthalmic division of existing registries for compilation and profiling of cases will further deepen our understanding of comorbidities associated with ocular COVID-19 infection and

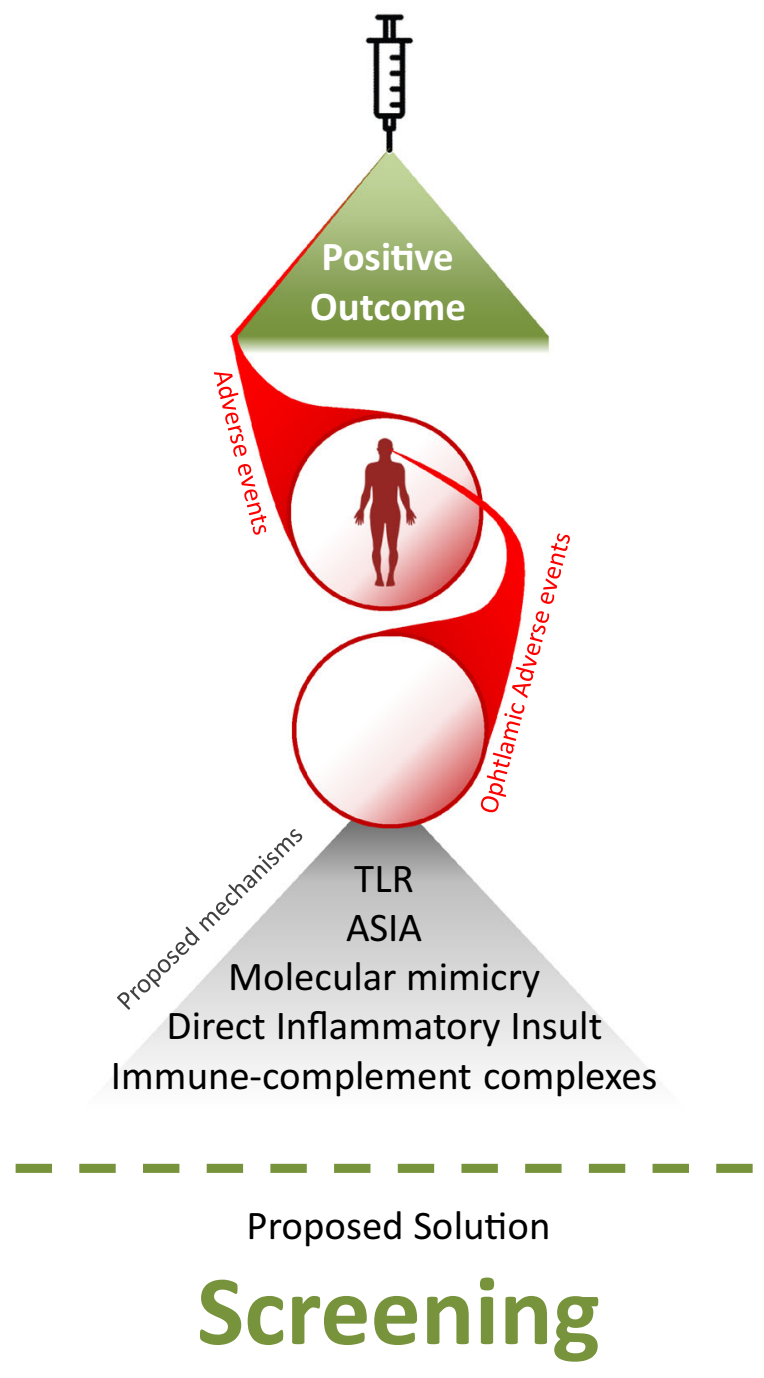

Fig. 6 The eye of the storm: COVID-19 vaccination and ocular adverse events 
vaccination. These cases may then be reviewed and evaluated with more consistent protocols developed to assess and follow up future possibilities. This would aid in the establishment of risk factors as well (Fig. 6).

\section{ACKNOWLEDGEMENTS}

Funding. No funding or sponsorship was received for this study or publication of this article.

Authorship. All named authors meet the International Committee of Medical Journal Editors (ICMJE) criteria for authorship for this article, take responsibility for the integrity of the work as a whole, and have given their approval for this version to be published. All named authors meet the International Committee of Medical Journal Editors (ICMJE) criteria for authorship for this article, take responsibility for the integrity of the work as a whole and have given their approval for this version to be published.

Author Contributions. Xin Le $\mathrm{Ng}$ and Rupesh Agrawal conceptualized and planned the review. Xin Le Ng, Bjorn Kaijun Betzler and Sean $\mathrm{Ng}$ reviewed the literature and wrote the manuscript. Xin Le Ng, Bjorn Kaijun Betzler, Sean Ng, Soon Phaik Chee, Lakshminarayanan Rajamani, Amit Singhal, Andres Rousselot, Carlos E Pavesio, Vishali Gupta, Marc D. de Smet and Rupesh Agrawal contributed to interpreting the results and provided critical feedback to the manuscript.

Disclosures. Rupesh Agrawal is supported by a grant from the National Medical Research Council (NMRC), Singapore, for the Clinician Scientist Award (CSA) from 2020-2023. He has not received funding for his work in this publication. Lakshminarayanan Rajamani thanks the funding support from the Duke SingHealth Duke-NUS COVID-19 Innovation grant (05/ FY2020/P2(C2)/06-A69). He has not received funding for his work in this publication. Xin Le $\mathrm{Ng}$, Bjorn Kaijun Betzler, Sean Ng, Soon Phaik
Chee, Amit Singhal, Andres Rousselot, Carlos E Pavesio, Vishali Gupta and Marc D. de Smet all confirm that they have nothing to disclose

Compliance with Ethics Guidelines. This review adhered to the tenets of the Declaration of Helsinki and as the research does not contain any patient data, specific ethical clearance was not required for this study based on our ethical committee guidelines. This article is based on previously conducted studies and does not contain any new studies with human participants or animals performed by any of the authors.

Data Availability. Data sharing is not applicable to this article as no datasets were generated or analyzed during the current study.

Open Access. This article is licensed under a Creative Commons Attribution-NonCommercial 4.0 International License, which permits any non-commercial use, sharing, adaptation, distribution and reproduction in any medium or format, as long as you give appropriate credit to the original author(s) and the source, provide a link to the Creative Commons licence, and indicate if changes were made. The images or other third party material in this article are included in the article's Creative Commons licence, unless indicated otherwise in a credit line to the material. If material is not included in the article's Creative Commons licence and your intended use is not permitted by statutory regulation or exceeds the permitted use, you will need to obtain permission directly from the copyright holder. To view a copy of this licence, visit http://creativecommons.org/licenses/bync/4.0/.

\section{REFERENCES}

1. Seah I, Agrawal R. Can the coronavirus disease 2019 (COVID-19) affect the eyes? A review of coronaviruses and ocular implications in humans and animals. Ocul Immunol Inflamm. 2020;28:391-5.

2. Detrick B, Lee MT, Chin MS, Hooper LC, Chan CC, Hooks JJ. Experimental coronavirus retinopathy 
(ECOR): retinal degeneration susceptible mice have an augmented interferon and chemokine (CXCL9, CXCL10) response early after virus infection. J Neuroimmunol. 2008;193:28-37.

3. Komurasaki Y, Nagineni CN, Wang Y, Hooks JJ. Virus RNA persists within the retina in coronavirusinduced retinopathy. Virology. 1996;222:446-50.

4. Chin MS, Hooper LC, Hooks JJ, Detrick B. Identification of $\alpha$-fodrin as an autoantigen in experimental coronavirus retinopathy (ECOR). J Neuroimmunol. 2014;272:42-50.

5. Gupta A, Madhavan MV, Sehgal K, Nair N, Mahajan S, Sehrawat TS, et al. Extrapulmonary manifestations of COVID-19. Nat Med. 2020;26:1017-32.

6. Armstrong L, Collin J, Mostafa I, Queen R, Figueiredo FC, Lako M. In the eye of the storm: SARS-CoV2 infection and replication at the ocular surface? Stem Cells Transl Med. 2021;10:976-86.

7. Scalinci SZ, Trovato BE. Conjunctivitis can be the only presenting sign and symptom of COVID-19. IDCases. 2020;20: e00774.

8. Otaif W, Al Somali AI, Al Habash A. Episcleritis as a possible presenting sign of the novel coronavirus disease: a case report. Am J Ophthalmol Case Rep. 2020;20:100917.

9. Méndez Mangana C, Barraquer Kargacin A, Barraquer RI. Episcleritis as an ocular manifestation in a patient with COVID-19. Acta Ophthalmol. 2020;98: e1056-7.

10. Mazzotta C, Giancipoli E. Anterior acute uveitis report in a SARS-CoV-2 patient managed with adjunctive topical antiseptic prophylaxis Preventing 2019-nCoV spread through the ocular surface route. Int Med Case Rep J. 2020;13:513-20.

11. Invernizzi A, Torre A, Parrulli S, Zicarelli F, Schiuma $\mathrm{M}$, Colombo V, et al. Retinal findings in patients with COVID-19: results from the SERPICO-19 study. EClinicalMedicine. 2020;27:100550.

12. Sawalha K, Adeodokun S, Kamoga GR. COVID-19induced acute bilateral optic neuritis. J Investig Med High Impact Case Rep. 2020;8: 2324709620976018.

13. Zhou S, Jones-Lopez EC, Soneji DJ, Azevedo CJ, Patel VR. Myelin oligodendrocyte glycoprotein antibody-associated optic neuritis and myelitis in COVID-19. J Neuroophthalmol. 2020;40:398-402.

14. Belghmaidi S, Nassih H, Boutgayout S, El Fakiri K, El Qadiry R, Hajji I, et al. Third cranial nerve palsy presenting with unilateral diplopia and strabismus in a 24-year-old woman with COVID-19. Am J Case Rep. 2020;21: e925897.

15. Oliveira RMC, Santos DH, Olivetti BC, Takahashi JT. Bilateral trochlear nerve palsy due to cerebral vasculitis related to COVID-19 infection. Arq Neuropsiquiatr. 2020;78:385-6.

16. Greer CE, Bhatt JM, Oliveira CA, Dinkin MJ. Isolated cranial nerve 6 palsy in 6 patients with COVID-19 infection. J Neuroophthalmol. 2020;40: 520-2.

17. Martínez Díaz M, Copete Piqueras S, Blanco Marchite C, Vahdani K. Acute dacryoadenitis in a patient with SARS-CoV-2 infection. Orbit. 2021. https://doi.org/10.1080/01676830.2020.1867193.

18. Wu P, Duan F, Luo C, Liu Q, Qu X, Liang L, et al. Characteristics of ocular findings of patients with coronavirus disease 2019 (COVID-19) in Hubei province. China JAMA Ophthalmol. 2020;138: 575-8.

19. Restivo DA, Centonze D, Alesina A, Marchese-Ragona R. Myasthenia gravis associated with SARSCoV-2 infection. Ann Intern Med. 2020;173: 1027-8.

20. Chau CYC, Chow LLW, Sridhar S, Shih KC. Ophthalmological considerations for COVID-19 vaccination in patients with inflammatory eye diseases and autoimmune disorders. Ophthalmol Ther. 2021;10:201-9.

21. Baxter R, Lewis E, Fireman B, DeStefano F, Gee J, Klein NP. Case-centered Analysis of optic neuritis after vaccines. Clin Infect Dis. 2016;63:79-81.

22. Agarwal A, Garg D, Goyal V, Pandit AK, Srivastava AK, Srivastava MP. Optic neuritis following antirabies vaccine. Trop Doct. 2020;50:85-6.

23. Arshi S, Sadeghi-Bazargani H, Ojaghi H, SavadiOskouei D, Hekmat S, Jastan M, et al. The first rapid onset optic neuritis after measles-rubella vaccination: case report. Vaccine. 2004;22:3240-2.

24. van de Geijn EJ, Tukkie R, van Philips LA, Punt H. Bilateral optic neuritis with branch retinal artery occlusion associated with vaccination. Doc Ophthalmol. 1994;86:403-8.

25. Basilious A, Jivraj I, DeAngelis D. Acute unilateral ptosis and myositis following the H1N1 influenza vaccine. Ophthalmic Plast Reconstr Surg. 2020;36: e16-7.

26. Liang Y, Meng FY, Pan HF, Ye DQ. A literature review on the patients with autoimmune diseases following vaccination against infections. Hum Vaccin Immunother. 2015;11:2274-80. 
27. Wraith DC, Goldman M, Lambert PH. Vaccination and autoimmune disease: what is the evidence? Lancet. 2003;362:1659-66.

28. Watad A, De Marco G, Mahajna H, Druyan A, Eltity $\mathrm{M}$, Hijazi N, et al. Immune-mediated disease flares or new-onset disease in 27 subjects following mRNA/DNA SARS-CoV-2 vaccination. Vaccines (Basel). 2021;9:435.

29. Teijaro JR, Farber DL. COVID-19 vaccines: modes of immune activation and future challenges. Nat Rev Immunol. 2021;21:195-7.

30. Rodero MP, Crow YJ. Type I interferon-mediated monogenic autoinflammation: The type I interferonopathies, a conceptual overview. J Exp Med. 2016;213:2527-38.

31. Ball P. The lightning-fast quest for COVID vaccines and what it means for other diseases. Nature. 2021;589:16-8.

32. Gargano JW, Wallace M, Hadler SC, Langley G, Su JR, Oster ME, et al. Use of mRNA COVID-19 vaccine after reports of myocarditis among vaccine recipients: update from the advisory committee on immunization practices-United States, June 2021. MMWR Morb Mortal Wkly Rep. 2021;70:977-82.

33. Del Bello A, Marion O, Delas A, Congy-Jolivet N, Colombat M, Kamar N. Acute rejection after antiSARS-CoV-2 mRNA vaccination in a patient who underwent a kidney transplant. Kidney Int. 2021;100:238-9.

34. Aleem A, Nadeem AJ. Coronavirus (COVID-19) vaccine-induced immune thrombotic thrombocytopenia (VITT). Treasure Island: StatPearls Publishing LLC; 2021.

35. Sanjay S, Mutalik D, Gowda S, Mahendradas P, Kawali A, Shetty R. Post coronavirus disease (COVID-19) reactivation of a quiescent unilateral anterior uveitis. SN Compr Clin Med. 2021. https:// doi.org/10.1080/02713683.2021.1905001.

36. Ozonoff A, Nanishi E, Levy O. Bell's palsy and SARSCoV-2 vaccines. Lancet Infect Dis. 2021;21:450-2.

37. Shemer A, Pras E, Einan-Lifshitz A, Dubinsky-Pertzov B, Hecht I. Association of COVID-19 vaccination and facial nerve palsy: a case-control study. JAMA Otolaryngol Head Neck Surg. 2021;147: 739-43.

38. Ish S, Ish P. Facial nerve palsy after COVID-19 vaccination: a rare association or a coincidence. Indian J Ophthalmol. 2021;69:2550-2.

39. Bayas A, Menacher M, Christ M, Behrens L, Rank A, Naumann M. Bilateral superior ophthalmic vein thrombosis, ischaemic stroke, and immune thrombocytopenia after ChAdOx1 $\mathrm{nCoV}-19$ vaccination. Lancet. 2021;397:e11.

40. Papasavvas I, Herbort CP Jr. Reactivation of VogtKoyanagi-Harada disease under control for more than 6 years, following anti-SARS-CoV-2 vaccination. J Ophthalmic Inflamm Infect. 2021;11:21.

41. Koong LR, Chee WK, Toh ZH, Ng XL, Agrawal R, Ho SL. Vogt-Koyanagi-harada disease associated with COVID-19 mRNA vaccine. Ocul Immunol Inflamm. 2021. https://doi.org/10.1080/09273948.2021. 1974492 .

42. ElSheikh RH, Haseeb A, Eleiwa TK, Elhusseiny AM. Acute uveitis following COVID-19 vaccination. Ocul Immunol Inflamm. 2021. https://doi.org/10. 1080/09273948.2021.1962917.

43. Michel T, Stolowy N, Gascon P, Dupessey F, Comet A, Attia R, et al. Acute macular neuroretinopathy after COVID-19 vaccine. J Ophthalmic Inflamm Infection. 2021. https://doi.org/10.21203/rs.3.rs$632137 / v 1$.

44. Mambretti M, Huemer J, Torregrossa G, Ullrich M, Findl O, Casalino G. Acute macular neuroretinopathy following coronavirus disease 2019 vaccination. Ocul Immunol Inflamm. 2019;2021: $1-4$.

45. Bøhler AD, Strøm ME, Sandvig KU, Moe MC, Jørstad ØK. Acute macular neuroretinopathy following COVID-19 vaccination. Eye (London). 2021. https://doi.org/10.1038/s41433-021-01610-1.

46. Valenzuela DA, Groth S, Taubenslag KJ, Gangaputra S. Acute macular neuroretinopathy following Pfizer-BioNTech COVID-19 vaccination. Am J Ophthalmol Case Rep. 2021;24:101200.

47. Phylactou M, Li JO, Larkin DFP. Characteristics of endothelial corneal transplant rejection following immunisation with SARS-CoV-2 messenger RNA vaccine. Br J Ophthalmol. 2021;105:893-6.

48. Wasser LM, Roditi E, Zadok D, Berkowitz L, Weill Y. Keratoplasty Rejection After the BNT162b2 messenger RNA Vaccine. Cornea. 2021;40:1070-2.

49. Ravichandran S, Natarajan R. Corneal graft rejection after COVID-19 vaccination. Indian J Ophthalmol. 2021;69:1953-4.

50. Rallis KI, Ting DSJ, Said DG, Dua HS. Corneal graft rejection following COVID-19 vaccine. Eye (London). 2021. https://doi.org/10.1038/s41433-02101671-2.

51. Pichi F, Aljneibi S, Neri P, Hay S, Dackiw C, Ghazi NG. Association of ocular adverse events with 
inactivated COVID-19 vaccination in patients in Abu Dhabi. JAMA Ophthalmol. 2021. https://doi. org/10.1001/jamaophthalmol.2021.3477.

52. Santovito LS, Pinna G. Acute reduction of visual acuity and visual field after Pfizer-BioNTech COVID-19 vaccine 2nd dose: a case report. Inflamm Res. 2021. https://doi.org/10.1007/s00011-02101476-9.

53. Mudie LI, Zick JD, Dacey MS, Palestine AG. Panuveitis following Vaccination for COVID-19. Ocul Immunol Inflamm. 2021. https://doi.org/10.1080/ 09273948.2021 .1949478 .

54. Reyes-Capo DP, Stevens SM, Cavuoto KM. Acute abducens nerve palsy following COVID-19 vaccination. J Am Assoc Pediatr Ophthalmol Strabismus. 2021. https://doi.org/10.1016/j.jaapos.2021.05.003.

55. Fowler N, Mendez Martinez NR, Pallares BV, Maldonado RS. Acute-onset central serous retinopathy after immunization with COVID-19 mRNA vaccine. Am J Ophthalmol Case Rep. 2021;23:101136.

56. Bialasiewicz AA, Farah-Diab MS, Mebarki HT. Central retinal vein occlusion occurring immediately after 2 nd dose of mRNA SARS-CoV-2 vaccine. Int Ophthalmol. 2021. https://doi.org/10.1007/ s10792-021-01971-2.

57. Goyal M, Murthy SI, Annum S. Bilateral multifocal choroiditis following COVID-19 vaccination. Ocul Immunol Inflamm. 2021. https://doi.org/10.1080/ 09273948.2021 .1957123$.

58. Leber HM, Sant'Ana L, da Konichi SNR, Raio MC, Mazzeo T, Endo CM, et al. acute thyroiditis and bilateral optic neuritis following SARS-CoV-2 vaccination with CoronaVac: a case report. Ocul Immunol Inflamm. 2021. https://doi.org/10.1080/ 09273948.2021 .1961815

59. Vera-Lastra O, Ordinola Navarro A, Cruz Domiguez MP, Medina G, Sánchez Valadez TI, Jara LJ. Two cases of graves' disease following SARS-CoV-2 vaccination: an autoimmune/inflammatory syndrome induced by adjuvants. Thyroid. 2021. https://doi. org/10.1089/thy.2021.0142.

60. Bragazzi NL, Hejly A, Watad A, Adawi M, Amital H, Shoenfeld Y. ASIA syndrome and endocrine autoimmune disorders. Best Pract Res Clin Endocrinol Metab. 2020;34:101412.

61. Cunningham ET Jr, Moorthy RS, Fraunfelder FW, Zierhut M. Vaccine-associated uveitis. Ocul Immunol Inflamm. 2019;27:517-20.

62. Garip A, Diedrichs-Möhring M, Thurau SR, Deeg CA, Wildner G. Uveitis in a patient treated with Bacille-Calmette-Guérin: possible antigenic mimicry of mycobacterial and retinal antigens. Ophthalmology. 2009;116:2457-62.e2.

63. Su YR, Chen MT, Xiong K, Bai L. Endogenous tolllike receptor 2 modulates Th1/Treg-Promoting Dendritic Cells In Mice Corneal Transplantation Model. Curr Eye Res. 2020;45:774-81.

64. Madendag Y, Acmaz G, Atas M, Sahin E, Tayyar AT, Madendag I, et al. The effect of oral contraceptive pills on the macula, the retinal nerve fiber layer, and choroidal thickness. Med Sci Monit. 2017;23: 5657-61.

65. Fuchsjäger-Mayrl G, Nepp J, Schneeberger C, Sator M, Dietrich W, Wedrich A, et al. Identification of estrogen and progesterone receptor mRNA expression in the conjunctiva of premenopausal women. Invest Ophthalmol Vis Sci. 2002;43:2841-4.

66. Bettach E, Zadok D, Weill Y, Brosh K, Hanhart J. Bilateral anterior uveitis as a part of a multisystem inflammatory syndrome secondary to COVID-19 infection. J Med Virol. 2021;93:139-40.

67. Benito-Pascual B, Gegúndez JA, Díaz-Valle D, Arriola-Villalobos P, Carreño E, Culebras E, et al. Panuveitis and optic neuritis as a possible initial presentation of the novel coronavirus disease 2019 (COVID-19). Ocul Immunol Inflamm. 2020;28: 922-5.

68. Yahalomi T, Pikkel J, Arnon R, Pessach Y. Central retinal vein occlusion in a young healthy COVID19 patient: a case report. Am J Ophthalmol Case Rep. 2020;20:92.

69. Chin D, Gan NY, Holder GE, Tien M, Agrawal R, Manghani M. Severe retinal vasculitis in systemic lupus erythematosus leading to vision threatening paracentral acute middle maculopathy. Mod Rheumatol Case Rep. 2021;5:265-71.

70. Fujinami RS, von Herrath MG, Christen U, Whitton JL. Molecular mimicry, bystander activation, or viral persistence: infections and autoimmune disease. Clin Microbiol Rev. 2006;19:80-94.

71. Wucherpfennig KW. Mechanisms for the induction of autoimmunity by infectious agents. J Clin Invest. 2001;108:1097-104.

72. Ferri C, Zignego AL. Relation between infection and autoimmunity in mixed cryoglobulinemia. Curr Opin Rheumatol. 2000;12:53-60.

73. Mathian A, Devilliers $H$, Krivine A, CostedoatChalumeau N, Haroche J, Huong DB, et al. Factors influencing the efficacy of two injections of a pandemic 2009 influenza A (H1N1) nonadjuvanted vaccine in systemic lupus erythematosus. Arthritis Rheum. 2011;63:3502-11. 
74. See I, Su JR, Lale A, Woo EJ, Guh AY, Shimabukuro TT, et al. US case reports of cerebral venous sinus thrombosis with thrombocytopenia after Ad26. COV2.S vaccination, march 2 to april 21, 2021. JAMA. 2021;325:2448-56.
75. Castelli GP, Pognani C, Sozzi C, Franchini M, Vivona L. Cerebral venous sinus thrombosis associated with thrombocytopenia post-vaccination for COVID-19. Crit Care. 2021;25:137. 